\title{
LEPTIN: ROLE OF METABOLISM IN THE REGULATION OF INFLAMMATION
}

\author{
Claudio Procaccini, Veronica De Rosa, Mario Galgani, Luisa Abanni, and Giuseppe Matarese \\ Institute of Endocrinology and Experimental Oncology, National Research Council, Department of \\ Biology and Cellular and Molecular Pathology, University "Federico II", Naples, Italy
}

Over the last few years the intricate interaction between immune system and adipose tissue has been recognized. Indeed, it has been suggested that adipose tissue is not only a mere site of lipid and energy storage but can be considered as an "immunerelated" organ producing a series of molecules named adipokines. Among these, leptin, an adipocyte-derived cytokine-like hormone, seems to play a pivotal role in the regulation of several neuroendocrine and immune functions. In this review, we describe the effects of leptin in inflammation and immunity, and speculate on the possible modulation of the leptin axis in novel adipopharmacotherapeutic settings. Biomed Rev 2006; 17: 53-62.

Key words: adipopharmacology, adipose tissue, autoimmunity, immune response

\section{INTRODUCTION}

The classic view of adipose tissue as a static reservoir of lipids necessary in time of reduced food availability in the environment is only a part of current adipobiology. Adipocytes as well as nonfat cells of the adipose tissue have been shown to secrete hormones, growth factors, cytokines and chemokines, collectively dubbed adipokines. These are necessary for various biological functions, including the endocrine and immune function. Consequently, a series of novel hypotheses on the role of adipose tissue as a key regulator of immune function and as a secondary "immune organ" has been generated. Indeed, it is well known that immune cells, such as lymphocytes, macrophages and mast cells, are present in adipose tissue. Furthermore, adipose tissue cells are able to secrete a large number of adipokines classically considered of immune origin, such as cytokines and chemokines.

Here, we present an overview of the immune functions mediated by leptin. Leptin is an adipokine which communicates information on energy availability and thus influences neuroendocrine and immune functions in animals and humans. Leptin primarily influences energy homeostasis and regulates

Received 2 November 2006, accepted 20 November 2006.

Correspondence and reprint request to Dr Giuseppe Matarese, Istituto di Endocrinologia e Oncologia Sperimentale, Consiglio Nazionale delle Ricerche, c/o Dipartimento di Biologia e Patologia Cellulare e Molecolare, Via S. Panini 5, 80131, Napoli, Italy. Tel.: 390817463 613, Fax: 390817463 252, Email: gmatarese@napoli.com 
neuroendocrine function in states of energy deficiency. As a cytokine, leptin affects thymic homeostasis and, similar to other pro-inflammatory cytokines, promotes $\mathrm{T}$ helper 1 (Th1)-cell differentiation and cytokine production. We review recent advances on the role of leptin in the pathophysiology of immune responses during inflammation, leptin as a promising target for adipopharmacology being also appreciated.

\section{LEPTIN AND LEPTIN SIGNALING IN IMMUNE CELLS}

Several recent observations show that leptin is a hormone/cytokine that is involved in immune-neuroendocrine crosstalk and functions as a key signal, coupling the metabolic axis to the immune system. Leptin, the product of the obese gene, is a 167 -aminoacid peptide hormone mainly synthesized by adipocytes. It regulates body weight by stimulating energy expenditure through increased thermogenesis and by suppressing food intake $(1,2)$. In addition, leptin is sexually dimorphic, its serum concentration being higher in females than in males with similar body fat mass. Leptin belongs structurally to the family of long-chain helical cytokines and has a similarity with interleukin-6 (IL-6), IL-12, IL-15, granulocyte colonystimulating factor (G-CSF), oncostatin M (OSM), prolactin and growth hormone $(3,4)$. The fact that leptin acts as a hormone and as a cytokine reinforces the concept that leptin links the endocrine to the immune system $(3,4)$. The effects of leptin are mediated by the long form receptor. Briefly, the leptin receptor $(\mathrm{ObR})$ is a member of the class I cytokine receptor superfamily and has at least six isoforms as a result of alternative splicing. All isoforms share an identical extracellular ligand-binding domain. Leptin's functional receptor $(\mathrm{ObRb})$ is expressed not only in the hypothalamus, where it regulates energy homeostasis and neuroendocrine function, but also in each cell type of the innate and adaptive immunity (5-8). $\mathrm{ObRb}$ is involved in several downstream signal transduction pathways and has been identified in immune cells of both animals and humans (5). Leptin binding to its functional receptor recruits Janus tyrosine kinases (JAK) and activates the receptor, which then serves as a docking site for cytoplasmic adaptors, such as signal transducer and activator of transcription (STAT) (9). These translocate to the nucleus and induce expression of other genes, including negative regulators, such as the suppressor of cytokine signaling 3 (SOCS3) (10) and the protein tyrosine phosphatase $1 \mathrm{~B}$ (11). A number of studies in human peripheral blood mononuclear cells (PBMC) have shown that, in addition to the JAK-2-STAT-3 pathway, which is an important pathway mediating leptin's effect on immune cells, other pathways are also involved. The mitogen activated protein kinase (MAPK), the insulin receptor substrate-1 (IRS1), and the phosphatidylinositol 3'-kinase (PI3'K) pathways (12) are also important pathways that mediate leptin's action on immune T cells (13). Moreover, in PBMC the MAPK pathway seems to mediate antiapoptotic effects (14) whereas the PI3' $\mathrm{K}$ pathway may be important in regulating glucose uptake (15). The role of Src associated in mitosis protein (Sam68), an RNA binding protein, regulator of RNA metabolism and effector of the PI3' $\mathrm{K}$ pathway, remains unclear, but it is currently thought to function as an adaptor protein by binding to activated STAT3 and to the p85 subunit of PI3'K (12).

\section{THE ROLE OF LEPTIN IN INNATE AND ADAPTIVE IMMUNITY}

In recent years, a number of studies investigated the effect of leptin on innate and adaptive immune responses (Fig. 1). In mouse monocytes/macrophages, leptin upregulates phagocytic function (16) via phospholipase activation (17) as well as proinflammatory cytokine secretion, such as tumor necrosis factor- $\alpha$ (TNF- $\alpha)$, IL-6, and IL-12 $(18,19)$. The augmenting effect of leptin in monocyte/macrophage function has also been confirmed in humans. Studies show that leptin stimulates the proliferation of human circulating monocytes in vitro and upregulates expression of activation markers, such as CD25 ( $\alpha$-chain of IL-2 receptor), CD71 (transferrin receptor), CD69, and CD38, while further increasing the expression of other activation markers already present at high levels on the surface of resting monocytes, such as HLA-DR, CD11b, and CD11c (20). In polymorphonuclear cells of healthy subjects leptin stimulates reactive oxygen species production (8) and chemotaxis (21) via a mechanism which remains controversial and may or may not involve interaction with monocytes (22). In natural killer cells leptin is involved in all processes of cell development, differentiation, proliferation, activation, and cytotoxicity (23). The effect is mediated via STAT-3 activation and upregulated expression of perforin and IL-2 genes (6).

The effect of leptin in adaptive immunity of mice has also been well studied. This arm of the immune system is almost infinitely adaptable, mediated by lymphocytes that predominantly recognize peptide-MHC complexes and provides a broad range of immune responses against molecular structures other than carbohydrates. The effects of leptin on modulation of the immune response have been shown in leptin-deficient $(o b / o b)$ mice and in humans with congenital deficiency of lep- 
tin, in which both metabolic disturbances and immune abnormalities, including decreased inflammatory cytokine secretion and thymic hypotrophy have been observed. These abnormalities are reversed by the administration of recombinant leptin in both mice and humans. Studies in leptin receptor deficient leptin-resistant $d b / d b$ mice suggest that leptin may induce lymphopoiesis, as suggested by the reduced colony-forming potential under conditions favoring lymphoid expansion of bone marrow cells from $d b / d b$ mice. Leptin also provides a survival signal for double positive $\mathrm{CD} 4^{+} \mathrm{CD} 8^{+}$and single positive $\mathrm{CD} 4^{+} \mathrm{CD} 8$ - thymocytes during the energy consuming process of T-lymphocyte maturation (24) (Fig. 1).

Studies in humans have further delineated the role of leptin in activation of lymphocytes. In contrast to monocytes/macrophages, leptin alone is unable to induce proliferation and activation of mature human peripheral blood lymphocytes unless it is co-administered with other non specific immunostimulants, in which case leptin results in induction of early (CD69) and late activation markers (CD25, CD71) in both $\mathrm{CD}^{+}$and $\mathrm{CD} 8^{+}$lymphocytes (25). However, the proliferative effect of leptin seems to be specific only for distinct lymphocyte subpopulations. More specifically, leptin induces proliferation of naive $\mathrm{CD}^{+}{ }^{+} \mathrm{CD} 45 \mathrm{RA}^{+} \mathrm{T}$ cells, but inhibits proliferation of memory $\mathrm{CD}^{+} \mathrm{CD} 45 \mathrm{RO}^{+} \mathrm{T}$ cells (26). At the functional level, leptin polarizes $\mathrm{T}$ helper (Th) cytokine production towards a proinflammatory (Th1, IFN- $\gamma$ ) rather than anti-inflammatory

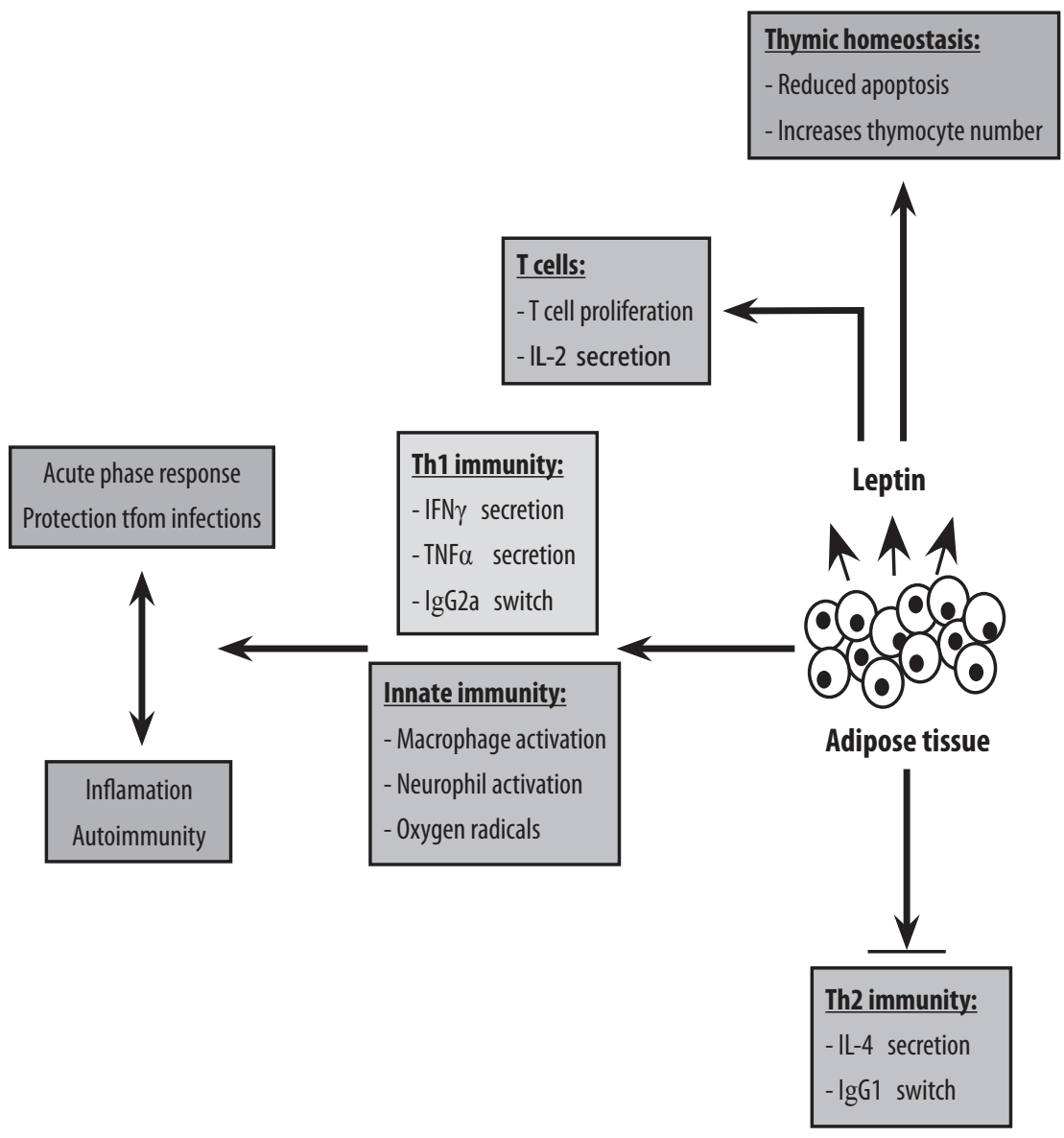

Figure 1. Effects of leptin on innate and adaptive immune responses. Leptin promotes the generation, maturation and survival of thymic T cells and increases proliferation and IL-2 secretion by naive T cells. In addition, leptin induces a switch towards Th1 immune response by increasing IFN- $\gamma$, TNF- $\alpha$ and IgG2a production and suppressing IL-4 secretion. On innate immunity, leptin promotes phagocytosis and oxygen radicals production. These effects sustain the immunity against pathogens and the acute phase response. At the same time, they may also promote inflammation and anti-self immune responses observed in autoimmune disorders. 
phenotype (Th2, IL-4) $(5,25)$ (Fig. 1). These effects may be mediated by promoting $\mathrm{T}$ lymphocyte survival by upregulating expression of antiapoptotic proteins, such as Bcl- $\mathrm{X}_{\mathrm{L}}(27)$ and T-bet (26), and synergize with other cytokines in lymphocyte proliferation and activation, possibly via STAT3 $(28,29)$.

\section{LEPTIN, INFLAMMATION AND ENHANCED ANTOIMMUNE RESPONSES}

The role of leptin in inflammation appears to be incompletely understood. Endogenous leptin protects against TNF-mediated toxicity. $O b / o b$ and $d b / d b$ mice, as well as mice treated with a leptin-receptor antagonist, had increased sensitivity to the lethal effects of TNF. The addition of exogenous leptin protected against TNF-mediated toxicity in $o b / o b$ mice, but did not increase the protective effect of endogenous leptin in wild-type mice (30). In the same way, animal models of leptin deficiency are protected from other toxic effects of innate immunity-mediated inflammation (such as LPS, zymosan-induced arthritis) (31). The mechanism for this presumed anti-inflammatory effect of leptin is unknown, but an imbalance between proinflammatory (unchanged) and antiinflammatory cytokines (IL-10 and IL-1 receptor antagonist are reduced) has been noted, raising the hypothesis that leptin may alter the production of anti-inflammatory cytokines by monocytes/macrophages via STAT-3 activation (32). In animals with adaptive immunity-mediated inflammation (Con A-induced hepatitis $(33,34)$, Clostridium difficile toxin A-induced enteritis (35) or antigen-induced arthritis (36)), leptin deficiency has a protective effect, resulting in reduced production of proinflammatory Th1 cytokines (34), and a shift towards a Th2 response (36). In these models, $o b / o b$ mice have less severe joint inflammation, reduced $\mathrm{T}$ cell proliferation, lower concentrations of specific antibodies, reduced expression of Th1-type cytokines and a bias towards the production of Th2-type cytokines. Importantly, inflammatory cells may themselves express and secrete leptin which may further foster the inflammatory process $(37,38)$.

Studies in mice: Several groups have investigated the susceptibility of $o b / o b$ and $d b / d b$ mice to experimentallyinduced autoimmune diseases (33-36,38-43). Susceptibility to experimental autoimmune encephalomyelitis (EAE), a model of multiple sclerosis (MS), has been investigated in $o b / o b$ mice before and after recombinant leptin administration (40). $\mathrm{Ob} / \mathrm{ob}$ mice are resistant to both actively and passively induced EAE but, consistent with leptin's Th1 promoting activities, these mice become susceptible to the disease after leptin administration. Resistance to EAE in $o b / o b$ mice is associated with a reduced proliferative response to myelin antigens and with an increased IL-4 response, whereas leptin replacement converted the Th2 response towards a Th1-type, leading to secretion of IFN- $\gamma$ and to an IgG1-to-IgG2a isotype switch. Leptin administration to susceptible wild-type mice also worsened the disease by increasing both proinflammatory cytokine levels and IgG2a production. These data were the first to show the action of leptin in a central nervous system (CNS) model of autoimmunity in vivo. More recently, it has also been shown that in different strains of EAE susceptible mice, such as $\mathrm{C} 57 \mathrm{BL} / 6 \mathrm{~J}$ and $\mathrm{SJL} / \mathrm{J}$, a serum leptin surge precedes disease onset and correlates with disease severity (38), inflammatory anorexia and development of pathogenic $\mathrm{T}$ cell responses (38). Furthermore, infiltrating T cells and macrophages in the CNS lesions stain positive for production of immunoreactive leptin, suggesting that leptin is also produced by immune cells during acute EAE.

The role of leptin and its receptor in the development of intestinal inflammation was recently described in an animal model in which the usual confounding factors of altered immune response, such as massive obesity, insulin-resistance, hyperglycaemia and hypercortisolemia were controlled for (43). It has been demonstrated that $\mathrm{T}$ cells from leptin-resistant $d b / d b$ mice display reduced capacity to induce colitis, upon passive transfer in T cell-deficient mice (scid mice). Transfer of T cells from $d b / d b$ mice induced delayed disease compared to transfer of wild-type cells. Histological examination of the colon early after the induction of disease revealed marked inflammation in mice injected with wild-type cells whereas no inflammation was observed in mice receiving $d b / d b$ cells. Lamina propria infiltrating lymphocytes (LPL) from both wild-type and $d b / d b$ mice showed no differences in terms of differentiation, expression of homing receptors and activation markers. Interestingly, the clearest difference was an increased rate of apoptosis of LPL derived from $d b / d b$ mice and a reduced production of inflammatory cytokines such as TNF- $\alpha$, IFN- $\gamma$, IL-1, IL- 6 and IL-18 and chemokines such as CXC-chemokine ligand 2 (CXCL2; macrophage inflammatory protein 2, MIP2) and CC-chemokine ligand 3 (CCL3; macrophage inflammatory protein 1, MIP1). Of interest, recent reports have shown that leptin secreted by the gastric mucosa is not completely degraded by proteolysis and can therefore reach the intestine in an active form, where it can control the 
expression of sodium/glucose and peptide transporters on intestinal epithelial cells (46). As a result, leptin might have a dual function in the gastrointestinal track: $(i)$ as a growth factor for the intestine, because of its involvement in the absorption of carbohydrates and proteins, and (ii) as a pivotal mediator of intestinal inflammation (44-46).

The role of leptin has also been investigated in spontaneous models of autoimmunity, such as type 1 diabetes mellitus (T1DM), in non-obese diabetic (NOD/LtJ) mice as well as in relation to the gender-related difference in susceptibility to autoimmune diseases. More specifically, early in life, leptin administration significantly increases inflammatory infiltrates in pancreatic islets, increases IFN- $\gamma$ production by T cells, anticipates the onset of T1DM, increases mortality and increases inflammatory infiltrates in pancreatic islets (42). Interestingly, it has also been shown that mouse strains spontaneously developing autoimmune diseases, such as NOD/LtJ and interleukin IL-2-deficient mice, have increased basal serum leptin before disease onset $(42,47)$. Of note, both of these strains of mice also have reduced numbers of circulating regulatory $\mathrm{T}$ cells, important in the induction and maintenance of $\mathrm{T}$ cell tolerance and protection from autoimmunity (48). These lines of evidence suggest that leptin could also affect regulatory $\mathrm{T}$ cell function by reversing the suppressive activity of these cells against potentially autoreactive $\mathrm{T}$ cells.

It is well known that the prevalence of autoimmune diseases (e.g., MS, rheumatoid arthritis, thyroiditis, and systemic lupus erythematosus) is increased in females (56). In addition to genetic, hormonal, or other factors that may account for this difference, serum leptin levels are higher in females than males even after controlling for body mass index. Thus, the role of leptin in possibly mediating this phenomenon has been investigated. Female SJL/J mice are susceptible to EAE induction with myelin-derived peptides when compared with disease-resistant males (39). Factors which could account for resistance to EAE in males are an increased Th2 response to myelin and reduced IL-12 production by antigen presenting cells (APC). Treatment with recombinant leptin rendered male $\mathrm{SJL} / \mathrm{J}$ mice susceptible to EAE induction and increased disease susceptibility in females. Treatment of males increased leptin levels to a concentration similar to that of EAE-susceptible females. These data suggest that leptin may prove to be one of the factors involved in the gender-related difference in susceptibility to autoimmune diseases and needs to be directly tested in humans.
Studies in humans: Animal models of autoimmunity have consistently shown that leptin may induce, accelerate or potentiate experimentally induced (38-41) or spontaneous autoimmunity (42). In addition, the beneficial role of hypocaloric diets, which decrease serum leptin levels, in control of autoimmunity in humans has been well documented (49). Moreover, recent clinical reports on patients with autoimmune diseases demonstrate that high serum leptin levels may be a contributing etiopathogenic factor (50-52) or a marker of disease activity (53-55).

Increased peripheral secretion of leptin in humans is associated with chronic inflammatory conditions, such as pelvic endometriosis, nonalcoholic hepatitis, chronic pulmonary inflammation, inflammatory bowel disease, inflammatory nephritis, Behcet's syndrome, thyroid-associated ophthalmopathy, T1DM, rheumatoid arthritis, metabolic syndrome, and atherosclerosis (34-43). However, one group has reported increased plasma levels of leptin in patients with rheumatoid arthritis compared with healthy controls (43), other groups have not confirmed this association (47). In a similar manner, the concentration of serum leptin has been found to be within the normal and/or physiological range in several inflammatory conditions (48-50). Sampling and disease staging should be carefully evaluated when interpreting the results of these studies. It is nonetheless common to find an increase in leptin concentration in the early phases of autoimmune diseases and before relapses (34-43). Intriguingly, food deprivation ameliorates the symptoms associated with some of these inflammatory conditions. For example, in rheumatoid arthritis, fasting (and subsequent decrease of serum leptin) leads to improvement of disease activity and a shift towards Th2-cell responses (51). Fasting and/or caloric deprivation, or dietary changes in controlled trials in humans, can ameliorate clinical symptoms of autoimmune diseases such as IBD and MS, and similar changes are also effective in ameliorating disease in animal models of systemic lupus erythematosus and Sjögren's syndrome $(37,52-57)$. However, it must also be considered that the fall of leptin levels subsequent to fasting is not the only event associated with reduced caloric intake. Other hormonal and stress-response-related changes need to be taken into account to explain the final outcome (often resulting in improvement of chronic inflammation).

Obesity, a hyperleptinemic state, is increasingly considered a chronic, low-grate inflammatory disease. It is associated with progressive adipose tissue infiltration by macrophages $(37,57)$ 
and mast cells that secrete proinflammatory cytokines (TNF- $\alpha$, IL-1 $\beta$ and IL-6) which stimulate adipocytes to further secrete leptin. Tumor necrosis factor- $\alpha$ can induce insulin resistance, which could in turn perpetuate a vicious cycle of macrophage recruitment, production of proinflammatory cytokines, and adipocyte dysfunction (58). It has thus been speculated that leptin, previously shown to be independently associated with several proinflammatory cytokines (59-61), and which is increased during several inflammatory states, may foster adaptive immunity-mediated inflammatory phenomena. We have recently directly tested this hypothesis by performing interventional studies involving recombinant methylated human leptin (rmetHuLeptin) administration to normal and obese humans to prove or disprove whether the above associations reflect a causal role for leptin. We demonstrated that rmetHuLeptin administration to increase circulating leptin levels to high physiologic or pharmacologic levels does not alter proinflammatory cytokine levels or immune function in subjects with leptin sufficiency or excess (in obesity) (45). These data indicate that, similar to neuroendocrine function, the main role of leptin may be to regulate immune function in leptin deficient and not leptin sufficient states.

The beneficial role of fasting or hypocaloric diets, which decrease serum leptin levels, in the control of autoimmunity in humans has been relatively well studied (49). A potential role for leptin is further supported by recent clinical reports on patients with autoimmune diseases, where high serum leptin levels may be a contributing pathogenic factor (50-52) or marker of disease activity (53-55). Moreover, in patients with rheumatoid arthritis, fasting for 7 days was sufficient to induce clinical and laboratory evidence of disease improvement (62), but a 7-day ketogenic diet showed only moderate clinical effect (63), indicating that the role of leptin in autoimmunity is still incompletely understood.

\section{LEPTIN AND CHRONIC INFLAMMATION: THE ENDOMETRIOSIS MODEL}

Endometriosis is a benign gynecological disease characterized by implantation and growth of endometrial tissue outside the uterus, mainly in the peritoneal cavity. Endometriosis is a good example of a chronic inflammatory disease, as it is sustained by multiple repeated events that lead to the coexistence of all signs of Galenus-Virchow's description of inflammation: rubor, calor, dolor, tumor, and functio laesa. The most accredited pathogenetic hypothesis of endometriosis involves endometrial tissue transported to the peritoneal cavity throughout the tubes (retrograde menstruation), adherence to the peritoneal wall, followed by proliferation and formation of endometriotic lesions (64). Since retrograde menstruation occurs in almost all women, "permissive" factors must operate to allow development of disease. Leptin may well be one of these factors as it promotes angiogenesis and induces the expression of Bcl-2, intercellular adhesion molecule 1, and matrix metalloproteinases (65). Interestingly, endometrial cells of women with endometriosis have altered expression of above mentioned molecules, and also increased secretion of TNF- $\alpha$, IL-1, and IL- 6 by peritoneal macrophages (66). More importantly, leptin concentrations in serum and peritoneal fluid of patients with pelvic endometriosis are increased, and the endometriotic tissue expresses the long signaling form of the leptin receptor (67). It has been suggested that leptin is central in favoring implantation, growth, and maintenance of ectopic endometrial cells after retrograde menstruation and in locally promoting neoangiogenesis and invasion of the extracellular matrix via increased expression of matrix metalloproteinases.

\section{ADIPOPHARMACOLOGY OF LEPTIN: IMMUNOTHERAPEUTIC APPLICATIONS, CURRENT EVIDENCE AND HYPOTHESES}

Leptin-based therapy is currently administered to a few cases of genetically leptin-deficient individuals and to morbidly obese non-leptin-deficient patients to reduce their food intake. This treatment is effective in genetically leptin-deficient individuals in restoring some of the impaired neuroendocrine functions and in controlling food intake and reproductive function. Conversely, in non-leptin-deficient obese patients the effect of leptin administration is modest on food intake and weight loss, probably due to leptin receptor desensitization caused by the already high circulating leptin. Although the above are the only therapeutic uses of leptin in humans, additional clinical applications could be hypothesized on the basis of the immunoregulatory properties of leptin on $\mathrm{CD} 4^{+}$ $\mathrm{T}$ cells. In immunodeficiency associated with reduced food intake, such as anorexia nervosa or HIV-1 infection, leptin levels as well as $\mathrm{CD}^{+} \mathrm{T}$ cell numbers and function do not increase and are often reduced (68-72). Leptin administration might be suggested to provide help for immunoreconstitution via increased thymic $\mathrm{T}$ cell output and cell-mediated Th1 immune responses. Increased Th1 responses may also be envisaged for resistant tuberculosis in immunocompromised 
hosts and in the context of vaccination protocols to boost immune responses. In animals with reduced leptin levels, which have reduced delayed-type hypersensitivity responses and increased $\mathrm{Th} 2$ responses (5), the administration of leptin completely restores delayed-type hypersensitivity reactivity as well as the Th1 phenotype. A possible side effect of leptin therapy in these immunocompromised hosts is the inhibition of food intake due to leptin's action on the hypothalamus. This side effect can be avoided by using leptin receptor agonists unable to cross the blood brain barrier. With this approach it would be possible to have the effects of leptin on peripheral tissues, including the immune system, and not on food intake. Moreover, modulation of circulating leptin levels may be considered as a new possible strategy to intervene on some inflammatory and autoimmune conditions. This approach could easily be applicable, as it would be possible to reduce circulating leptin by caloric deprivation, thus overcoming some disadvantages of other cytokine-based therapies. In addition to starvation, diets rich in polyunsaturated fatty acids (n-3, fish oil), and low in saturated fatty acids, and/or zinc-free, could also be considered to diminish circulating leptin with little effects on body fat composition $(73,74)$. Clinical trials involving starvation to modulate proinflammatory responses in human autoimmune diseases have already been reported as successful (75). A better understanding of the role of leptin in the modulation of inflammation and autoimmunity is a yet little explored, but promising adipopharmacological approach. It may possibility lead to the addition of novel interesting tools to the armamentarium of the current immunotherapies for inflammation and autoimmune conditions.

\section{CONCLUSION}

There are still many questions concerning the role of several molecules, including leptin and other adipokines, at the interface between metabolism and immunity in the regulation of these two systems. Significant leaps of knowledge have been done in recent years in expanding the field of adipobiology and adipopharmacology of such molecules. While new information is unveiling the complexity connecting metabolism and immunity, further research is still needed. This should consider the adipose tissue an active participant in the regulation of essential body processes, with prominent roles particularly in the balance of inflammation and immune homeostasis.

\section{REFERENCES}

1. Zhang Y, Proenca R, Maffei M, Barone M, Leopold L, Friedman J. Positional cloning of the mouse obese gene and its human homologue. Nature 1994; 372: 425-432.

2. Zhang F, Basinski MB, Beals JM, Briggs SL, Churgay LM, Clawson DK et al. Crystal structure of the obese protein leptin-E100. Nature 1997; 387: 206-209.

3. Tartaglia LA. The leptin receptor. J Biol Chem 1997; 272: 6093-6096.

4. Tartaglia LA, Dembski M, Weng X, Deng N, Culpepper R, Devos R et al. Identification and expression cloning of a leptin receptor, OB-R. Cell 1995; 83: 1263-1271.

5. Lord GM, Matarese G, Howard JK, Baker RJ, Bloom SR, Lechler RI. Leptin modulates the T-cell immune response and reverses starvation-induced immunosuppression. Nature 1998; 394: 897-901.

6. Zhao Y, Sun R, You L, Gao C, Tian Z. Expression of leptin receptors and response to leptin stimulation of human natural killer cell lines. Biochem Biophys Res Commun 2003; 300: 247-252.

7. Zarkesh-Esfahani H, Pockley G, Metcalfe RA, Bidlingmaier M, Wu Z, Ajami A et al. High-dose leptin activates human leukocytes via receptor expression on monocytes. $J$ Immunol 2001; 167: 4593-4599.

8. Caldefie-Chezet F, Poulin A, Tridon A, Sion B, Vasson MP. Leptin: a potential regulator of polymorphonuclear neutrophil bactericidal action? J Leukoc Biol 2001; 69: 414-418.

9. Baumann H, Morella KK, White DW, Dembski M, Bailon PS, Kim H et al. The full-length leptin receptor has signaling capabilities of interleukin 6-type cytokine receptors. Proc Natl Acad Sci USA 1996; 93: 8374-8378.

10. Bjorbaek C, El Haschimi K, Frantz JD, Flier JS. The role of SOCS-3 in leptin signaling and leptin resistance. J Biol Chem 1999; 274: 30059-30065.

11. Cheng A, Uetani N, Simoncic PD, Chaubey VP, Lee-Loy A, McGlade CJ et al. Attenuation of leptin action and regulation of obesity by protein tyrosine phosphatase $1 \mathrm{~B}$. Dev Cell 2002; 2: 497-503.

12. Martin-Romero C, Sanchez-Margalet V. Human leptin activates PI3K and MAPK pathways in human peripheral blood mononuclear cells: possible role of Sam68. Cell Immunol 2001; 212: 83-91.

13. Sanchez-Margalet V, Martin-Romero C. Human leptin signaling in human peripheral blood mononuclear cells: 
activation of the JAK-STAT pathway. Cell Immunol 2001; 211: 30-36.

14. Najib S, Sanchez-Margalet V. Human leptin promotes survival of human circulating blood monocytes prone to apoptosis by activation of $\mathrm{p} 42 / 44$ MAPK pathway. Cell Immunol 2002; 220: 143-149.

15. Bates SH, Gardiner JV, Jones RB, Bloom SR, Bailey CJ. Acute stimulation of glucose uptake by leptin in 16 muscle cells. Horm Metab Res 2002; 34: 111-115.

16. Mancuso P, Gottschalk A, Phare SM, Peters-Golden M, Lukacs NW, Huffnagle GB. Leptin-deficient mice exhibit impaired host defense in Gram-negative pneumonia. $J$ Immunol 2002; 168: 4018-4024.

17. Mancuso P, Canetti C, Gottschalk A, Tithof PK, PetersGolden M. Leptin augments alveolar macrophage leukotriene synthesis by increasing phospholipase activity and enhancing group IVC iPLA2 (cPLA2gamma) protein expression. Am J Physiol Lung Cell Mol Physiol 2004; 287: L497-L502.

18. Loffreda S, Yang SQ, Lin HZ, Karp CL, Brengman ML, Wang DJ et al. Leptin regulates proinflammatory immune responses. FASEB J 1998; 12: 57-65.

19. Gainsford T, Willson TA, Metcalf D, Handman E, McFarlane C, Ng A et al. Leptin can induce proliferation, differentiation, and functional activation of hemopoietic cells. Proc Natl Acad Sci USA 1996; 93: 14564-14568.

20. Santos-Alvarez J, Goberna R, Sanchez-Margalet V. Human leptin stimulates proliferation and activation of human circulating monocytes. Cell Immunol 1999; 194: 6-11.

21. Caldefie-Chezet F, Poulin A, Vasson MP. Leptin regulates functional capacities of polymorphonuclear neutrophils. Free Radic Res 2003; 37: 809-814.

22. Zarkesh-Esfahani H, Pockley AG, Wu Z, Hellewell PG, Weetman AP, Ross RJ. Leptin indirectly activates human neutrophils via induction of TNF-alpha. J Immunol 2004; 172: 1809-1814.

23. Tian Z, Sun R, Wei H, Gao B. Impaired natural killer (NK) cell activity in leptin receptor deficient mice: leptin as a critical regulator in NK cell development and activation. Biochem Biophys Res Commun 2002; 298: 297-302.

24. Howard JK, Lord GM, Matarese G, Vendetti S, Ghatei MA, Ritter MA et al. Leptin protects mice from starvation-induced lymphoid atrophy and increases thymic cellularity in ob/ob mice. J Clin Invest 1999; 104: 1051-1059.

25. Martin-Romero C, Santos-Alvarez J, Goberna R, Sanchez-
Margalet V. Human leptin enhances activation and proliferation of human circulating T lymphocytes. Cell Immunol 2000; 199: 15-24.

26. Lord GM, Matarese G, Howard JK, Bloom SR, Lechler RI. Leptin inhibits the anti-CD3-driven proliferation of peripheral blood $\mathrm{T}$ cells but enhances the production of proinflammatory cytokines. J Leukoc Biol 2002; 72: 330338.

27. Fujita Y, Murakami M, Ogawa Y, Masuzaki H, Tanaka M, Ozaki S et al. Leptin inhibits stress-induced apoptosis of T lymphocytes. Clin Exp Immunol 2002; 128: 21-26.

28. Akaishi H, Takeda K, Kaisho T, Shineha R, Satomi S, Takeda J et al. Defective IL-2-mediated IL-2 receptor alpha chain expression in Stat3-deficient $\mathrm{T}$ lymphocytes. Int Immunol 1998: 10: 1747-1751.

29. Takeda K, Kaisho T, Yoshida N, Takeda J, Kishimoto T, Akira S. Stat3 activation is responsible for IL-6-dependent $T$ cell proliferation through preventing apoptosis: generation and characterization of T cell-specific Stat3-deficient mice. J Immunol 1998; 161: 4652-4660.

30. Takashi N, Waelput W, Guisez Y. Leptin is an endogenous protective protein against the toxicity exerted by tumor necrosis factor. $J$ Exp Med 1999; 189: 207-212.

31. Bernotiene E, Palmer G, Talabot-Ayer D, Szalay-Quinodoz I, Aubert ML, Gabay C. Delayed resolution of acute inflammation during zymosan-induced arthritis in leptindeficient mice. Arthritis Res Ther 2004; 6: R256-R263.

32. Williams L, Bradley L, Smith A, Foxwell B. Signal transducer and activator of transcription 3 is the dominant mediator of the anti-inflammatory effects of IL-10 in human macrophages. J Immunol 2004; 172: 567-576.

33. Siegmund B, Lear-Kaul KC, Faggioni R, Fantuzzi G. Leptin deficiency, not obesity, protects mice from Con A-induced hepatitis. EurJ Immuno. 2002; 32: 552-560.

34. Faggioni R, Jones-Carson J, Reed DA, Dinarello A, Feingold R, Grunfeld C et al. Leptin-deficient (ob/ob) mice are protected from $\mathrm{T}$ cell-mediated hepatotoxicity: role of tumor necrosis factor alpha and IL-18. Proc Natl Acad Sci USA 2000; 97: 2367-2372.

35. Mykoniatis A, Anton PM, Wlk M, Wang C, Ungsunan L, Bluher $\mathrm{S}$ et al. Leptin mediates Clostridium difficile toxin A-induced enteritis in mice. Gastroenterology 2003; 124: 683-691.

36. Busso N, So A, Chobaz-Peclat V, Morard C, Martinez-Soria $\mathrm{E}$, Talabot-Ayer $\mathrm{D}$ et al. Leptin signaling deficiency 
impairs humoral and cellular immune responses and attenuates experimental arthritis. J Immunol 2002; 168: 875-882.

37. Xu H, Barnes GT, Yang Q, Tan G, Yang D, Chou CJ et al. Chronic inflammation in fat plays a crucial role in the development of obesity-related insulin resistance. $J$ Clin Invest 2003; 112: 1821-1830.

38. Sanna V, Di Giacomo A, La Cava A, Lechler RI, Fontana S, Zappacosta S et al. Leptin surge precedes onset of autoimmune encephalomyelitis and correlates with development of pathogenic T cell responses. J Clin Invest 2003; 111: 241-250.

39. Matarese G, Sanna V, Di Giacomo A, Lord GM, Howard JK, Bloom SR et al. Leptin potentiates experimental autoimmune encephalomyelitis in SJL female mice and confers susceptibility to males. Eur J Immunol 2001; 31: 1324-1332.

40. Matarese G, Di Giacomo A, Sanna V, Lord GM, Howard JK, Di Tuoro A et al. Requirement for leptin in the induction and progression of autoimmune encephalomyelitis. J Immunol 2001; 166: 5909-5916.

41. Tarzi RM, Cook HT, Jackson I, Pusey CD, Lord GM. Leptin-deficient mice are protected from accelerated nephrotoxic nephritis. Am J Pathol 2004; 164: 385-390.

42. Matarese G, Sanna V, Lechler RI, Sarvetnick N, Fontana $\mathrm{S}$, Zappacosta $\mathrm{S}$ et al. Leptin accelerates autoimmune diabetes in female NOD mice. Diabetes 2002; 51: 13561361.

43. Siegmund B, Sennello A, Jones-Carson J, Gamboni-Robertson F, Lehr HA, Batra A et al. Leptin receptor expression on $\mathrm{T}$ lymphocytes modulates chronic intestinal inflammation in mice. Gut 2004; 53: 965-972.

44. Rabinovitch A, Suarez-Pinzon WL, Sorensen O, Rajotte RV, Power RF. TNF-alpha down-regulates type 1 cytokines and prolongs survival of syngeneic islet grafts in nonobese diabetic mice. J Immunol 1997; 159: 6298-6303.

45. Chan JL, Bullen J, Stoyneva V, DePaoli AM, Addy C, Mantzoros CS. r-metHuLeptin administration to achieve high physiologic or pharmacologic leptin levels does not alter circulating inflammatory marker levels in humans with leptin sufficiency or excess. J Clin Endocrinol Metab 2005.

46. Faggioni R, Fantuzzi G, Gabay C, Moser A, Dinarello A, Feingold $\mathrm{R}$ et al. Leptin deficiency enhances sensitivity to endotoxin-induced lethality. Am J Physiol 1999; 276:

\section{R136-R142.}

47. Gaetke LM, Oz HS, de Villiers WJ, Varilek GW, Frederich $\mathrm{RC}$. The leptin defense against wasting is abolished in the IL-2-deficient mouse model of inflammatory bowel disease. J Nutr 2002; 132: 893-896.

48. Sakaguchi S. Naturally arising CD4+ regulatory T cells for immunologic self-tolerance and negative control of immune responses. Annu Rev Immunol 2004; 22: 531-562.

49. Kjeldsen-Kragh J, Haugen M, Borchgrevink CF, Laerum E, Eek M, Mowinkel P et al. Controlled trial of fasting and one-year vegetarian diet in rheumatoid arthritis. Lancet 1991; 338: 899-902.

50. Mazziotti G, Parkes AB, Lage M, Premawardhana LD, Casanueva FF, Lazarus JH. High leptin levels in women developing postpartum thyroiditis. Clin Endocrinol 2004; 60: 208-213.

51. Zhan M, Zhao H, Yang R, Han ZC. Serum leptin levels in patients with idiopathic thrombocytopenic purpura. Eur J Haematol 2004; 72: 348-352.

52. Garcia-Gonzalez A, Gonzalez-Lopez L, Valera-Gonzalez IC, Cardona-Munoz EG, Salazar-Paramo M, GonzalezOrtiz M et al. Serum leptin levels in women with systemic lupus erythematosus. Rheumatol Int 2002; 22:138-141.

53. Batocchi AP, Rotondi M, Caggiula M, Frisullo G, Odoardi $\mathrm{F}$, Nociti $\mathrm{V}$ et al. Leptin as a marker of multiple sclerosis activity in patients treated with interferon-beta. $\mathrm{J} \mathrm{Neu}$ roimmunol 2003; 139:150-154.

54. Frisullo G, Angelucci F, Mirabella M, Caggiula M, Patanella K, Nociti V et al. Leptin enhances the release of cytokines by peripheral blood mononuclear cells from relapsing multiple sclerosis patients. J Clin Immunol 2004; 24: 287-293.

55. Evereklioglu C, Inaloz HS, Kirtak N, Doganay S, Bulbul $\mathrm{M}$, Ozerol E et al. Serum leptin concentration is increased in patients with Behcet's syndrome and is correlated with disease activity. Br J Dermatol 2002; 147: 331-336.

56. O'Shea JJ, Ma A, Lipsky P. Cytokines and autoimmunity. Nat Rev Immunol 2002; 2: 37-45.

57. Weisberg SP, McCann D, Desai M, Rosenbaum M, Leibel RL, Ferrante AW. Obesity is associated with macrophage accumulation in adipose tissue. $J$ Clin Invest 2003; 112: 1796-1808.

58. Wellen KE, Hotamisligil GS. Obesity-induced inflammatory changes in adipose tissue. $J$ Clin Invest 2003; 112: 1785-1788. 
59. Mantzoros CS, Moschos S, Avramopoulos I, Kaklamani V, Liolios A, Doulgerakis DE et al. Leptin concentrations in relation to body mass index and the tumor necrosis factor-alpha system in humans. J Clin Endocrinol Metab 1997; 82: 3408-3413.

60. Papathanassoglou ED, Moynihan JA, Ackerman MH, Mantzoros CS. Serum leptin levels are higher but are not independently associated with severity or mortality in the multiple organ dysfunction/systemic inflammatory response syndrome: a matched case control and a longitudinal study. Clin Endocrinol (Oxf) 2001; 54: 225-233.

61. Shamsuzzaman AS, Winnicki M, Wolk R, Svatikova A, Phillips BG, Davison DE et al. Independent association between plasma leptin and C-reactive protein in healthy humans. Circulation 2004; 109: 2181-2185.

62. Fraser DA, Thoen J, Reseland JE, Forre O, KjeldsenKragh J. Decreased CD4+ lymphocyte activation and increased interleukin-4 production in peripheral blood of rheumatoid arthritis patients after acute starvation. Clin Rheumatol 1999; 18: 394-401.

63. Fraser DA, Thoen J, Bondhus S, Haugen M, Reseland JE, Djoseland $\mathrm{O}$ et al. . Reduction in serum leptin and IGF-1 but preserved T-lymphocyte numbers and activation after a ketogenic diet in rheumatoid arthritis patients. Clin Exp Rheumatol 2000; 18: 209-214.

64. Oral E, Arici A. Pathogenesis of endometriosis. Obset Gynecol Clin North Am 1997; 24: 219-233.

65. Park HY, Kwon HM, Lim HJ, Hong BK, Lee JY, Park BE et al. Potential role of leptin in angiogenesis: leptin induces endothelial cell proliferation and expression of matrix metalloproteinases in vivo and in vitro. Exp Mol Med 2001; 33: 95-102.

66. Vinatier D, Dufour P. Is endometriosis an immunological disease? Contracept Fertil Sex 1997; 25: 179-191.

67. Devoto L, Caballero-Campo P, Jasper M, Mercader A, Devoto L, Pellicer A et al. Leptin and leptin receptor are expressed in the human endometrium and endometrial leptin secretion is regulated by human blastocyst. J Clin Endocrinol Metab 2000; 85: 4883-4888.

68. Tolle V, Kadem M, Bluet-Pajot MT, Frere D, Foulon C, Bossu $\mathrm{C}$ et al. Balance in ghrelin and leptin plasma levels in anorexia nervosa patients and constitutionally thin women. J Clin Endocrinol Metab 2003; 88:109-116.

69. Allende LM, Corell A, Manzanares J, Madruga D, Marcos A, Madrono A et al. Immunodeficiency associated with anorexia nervosa is secondary and improves after refeeding. Immunology 1998; 94:543-551.

70. Ballinger A, Kelly P, Hallyburton E, Besser R, Farthing M. Plasma leptin in chronic inflammatory bowel disease and HIV: implications for the pathogenesis of anorexia and weight loss. Clin Sci (Colch) 1998; 94: 479-483.

71. Grunfeld C, Pang M, Shigenaga JK, Jensen P, Lallone $\mathrm{R}$, Friedman J et al. Serum leptin levels in the acquired immunodeficiency syndrome. J Clin Endocrinol Metab 1996; 81: 4342-4346.

72. Matarese G, Castelli-Gattinara G, Cancrini C, Bernardi S, Romiti ML, Savarese C et al. Serum leptin and CD4+ $\mathrm{T}$ lymphocytes in HIV+ children during highly active antiretroviral therapy. Clin Endocrinol (Oxf) 2002; 57: 643-646.

73. Reseland JE, Haugen F, Hollung K, Solvoll K, Halvorsen $\mathrm{B}$, Brude IR et al. Reduction of leptin gene expression by dietary polyunsaturated fatty acids. J Lipid Res 2001; 42: 743-750.

74. Mantzoros CS, Prasad AS, Beck FW, Grabowski S, Kaplan J, Adair C et al. Zinc may regulate serum leptin concentrations in humans. J Am Coll Nutr 1998; 17: 270-275.

75. Fraser DA, Thoen J, Reseland JE, Forre O, KjeldsenKragh J. Decreased CD4+ lymphocyte activation and increased interleukin-4 production in peripheral blood of rheumatoid arthritis patients after acute starvation. Clin Rheumatol 1999; 18: 394-401. 